\title{
Surgical approach for acute ischemic colitis after scuba diving: A case report
}

\author{
Eun Soo Choi, M.D., ${ }^{1}$ ㄴ Han Deok Kwak, M.D., ${ }^{2}$ ๑ Jae Kyun Ju, M.D. ${ }^{2}$
}

\author{
'Department of General Surgery, KS Hospital, Gwangju-Korea \\ ${ }^{2}$ Division of Colorectal Surgery, Department of General Surgery, Chonnam National University Hospital, Gwangju-Korea
}

\begin{abstract}
The clinical manifestations that may occur due to decompression during scuba diving vary widely, but only mild symptoms have been reported mainly in the gastrointestinal tract. In particular, ischemic colitis caused by air embolism is rare. We report a case of full-thickness ischemic colitis treated with failed conservative treatment but successfully treated surgically. The case that was presented here suggests that decompression after scuba diving may cause severe symptoms in the gastrointestinal tract and may require a surgical approach. Treatment depends on the severity of the symptoms and the patient's condition, but surgical approaches should be considered.
\end{abstract}

Keywords: Acute ischemic colitis; air embolism; decompression sickness; scuba diving; surgical approach.

\section{INTRODUCTION}

The incidence of decompression sickness after scuba diving has been reported to be 1.27 to 1.52 per 1000 dives, ${ }^{[1]}$ and $>$ I,000 diving-related injuries are reported annually. ${ }^{[2]}$

When pulmonary barotrauma or decompression sickness occurs, gas bubbles may form and enter the systemic circulation, causing embolization or organ ischemia. Such air embolism may damage musculoskeletal, cutaneous, lymphatic, and neurological systems. ${ }^{[3]}$

Approximately $13 \%$ of the divers develop aerophagia at the time of ascent and complain of gastrointestinal symptoms. ${ }^{[4]}$ The main complaints include symptoms of abdominal pain, nausea, vomiting, and abdominal distension. Gastrointestinal barotrauma has been reported, though rarely, to cause serious gastrointestinal symptoms, such as gastric perforation or small bowel infarction due to thrombosis. ${ }^{[5,6]}$ Hyperbaric oxygen therapy and other conservative therapies are usually effective, but may sometimes cause serious symptoms due to air embolism. ${ }^{[7]}$
Air embolism may cause ischemic colitis, but it is rare. Here, we report a case of surgical treatment of full-thickness ischemic colitis due to air embolism.

\section{CASE REPORT}

A 58-year-old man visited our emergency department with diffuse abdominal pain and bloody diarrhea two days before his admission to our emergency department. The patient was a skilled diver who caught seafood by diving for 30 years. Two days before, he experienced severe abdominal pain after diving for two hours at a depth of $30 \mathrm{~m}$. He was immediately transferred to a local hospital and received hyperbaric oxygen therapy for two days. However, his symptoms did not improve, so he was referred to our emergency department.

His medical history indicated no underlying disease. At the time of admission, he was normotensive and afebrile, and his pulse rate was $120 / \mathrm{min}$ and respiratory rate was $20 / \mathrm{min}$. Physical examination revealed diffuse abdominal tenderness, mild abdominal distension, and anuria. The initial laboratory findings were as follows: white blood cell count, $2.7 \times 10^{3} / \mu \mathrm{L}$;

Cite this article as: Choi ES, Kwak HD, Ju JK. Surgical approach for acute ischemic colitis after scuba diving: A case report. Ulus Travma Acil Cerrahi Derg 2020;26:00-00

Address for correspondence: Jae Kyun Ju, M.D.

Jebongro 42, Dongu 61469 Gwangju - South Korea

Tel: 82010899II504 E-mail: eschoi83@gmail.com

Ulus Travma Acil Cerrahi Derg 2020;26(3):00-00 DOI: 10.14744/tjtes.2019.67523 Submitted: 26.12.2018 Accepted: 06.02.2019 Online: 25.02.2020

Copyright 2020 Turkish Association of Trauma and Emergency Surgery 


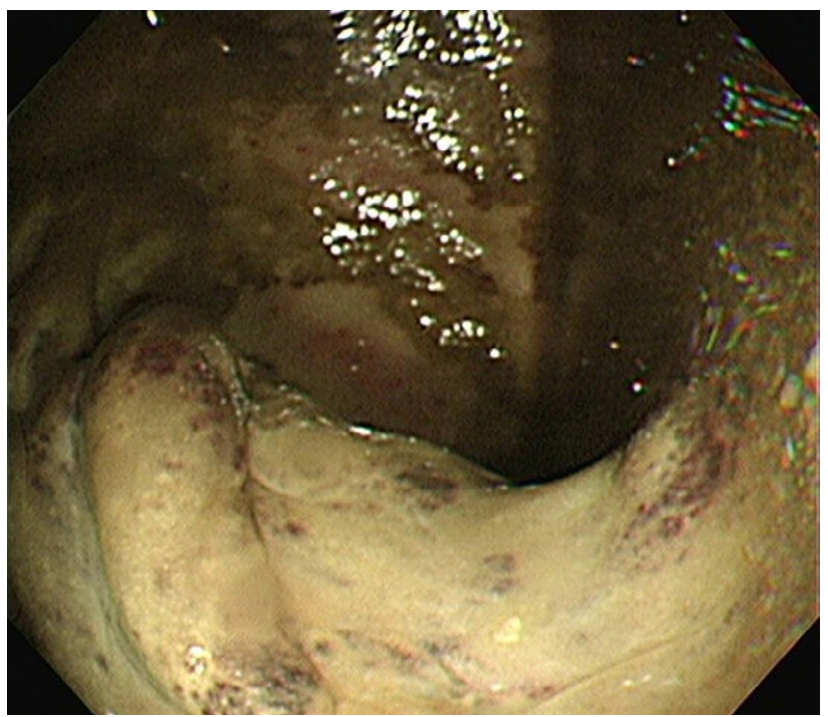

Figure 1. Sigmoidoscopy. Diffuse huge ulcerative lesion and mucosal swelling in the mid rectum to the mid sigmoid colon.

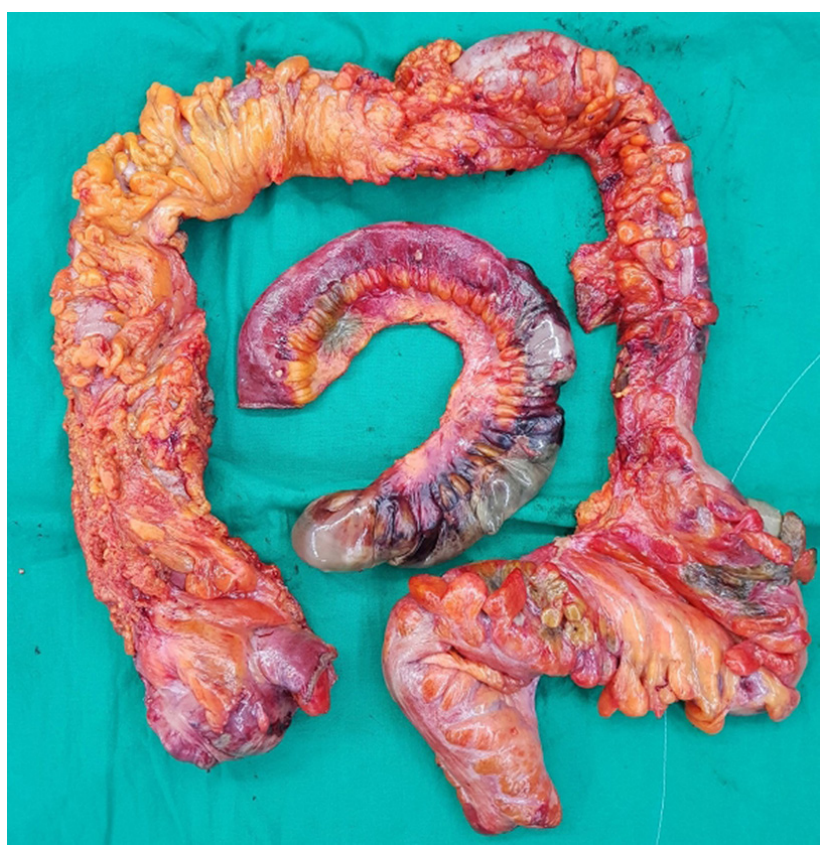

Figure 2. Resected specimen. Resected specimen showing multifocal necrosis in the terminal ileum, colon and rectum.

blood urea nitrogen (BUN)/creatinine ( $\mathrm{Cr}$ ) level, 87.6/4.99 $\mathrm{mg} / \mathrm{dL}$; C-reactive protein (CRP) level, $33.9 \mathrm{mg} / \mathrm{dL}$; lactate level, $3.32 \mathrm{mg} / \mathrm{dL}$ and creatine kinase $1267 \mathrm{IU} / \mathrm{L}$. Other laboratory findings, including coagulation and urinalysis profiles, were within the normal ranges. Elevated serum creatinine level and anuria were detected, and continuous renal replacement therapy (CRRT) was initiated under the diagnosis of sepsis-induced acute renal failure.

Nonenhanced abdomen computerized tomography (CT) and high-resolution chest $\mathrm{CT}$ were performed. Abdominal $\mathrm{CT}$ revealed no specific finding except mild small bowel ileus. Chest CT revealed centrilobular emphysema in both the upper (a)
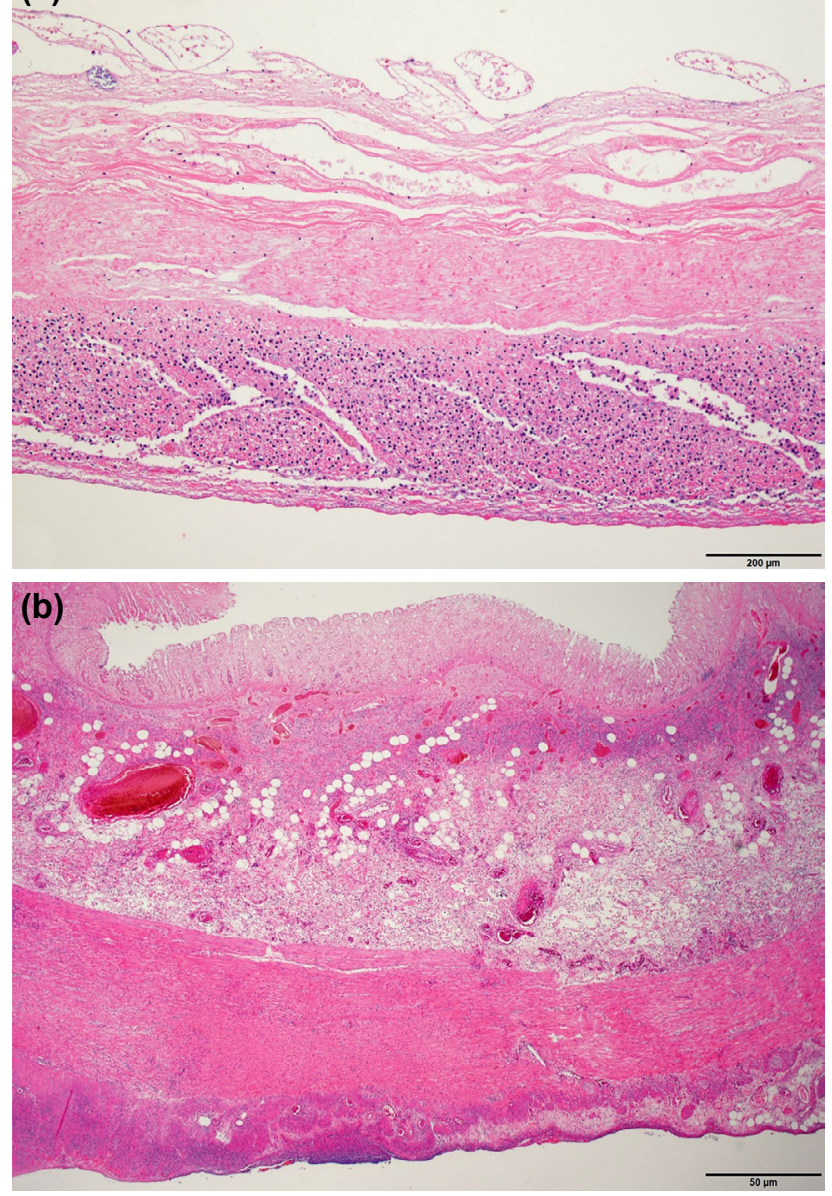

Figure 3. A: Terminal ileum; B: Colon. (a) Thinning mucosa, fat necrosis, infiltration of inflammatory cells, and necrosis of serosa showing typical transmural infarct findings. (b) Mucosa crypt necrosis, inflammatory cell infiltration across all layers, and serosa suppurative inflammation and abscess showing typical necrotizing inflammation.

lungs and atelectasis in both lower lungs. After admission to the intensive care unit, on follow-up abdominal computerized tomography angiography (ACTA), the terminal ileum, ascending and sigmoid colon, and rectum showed decreased enhancement and wall thickening with inflammatory infiltration of surrounding tissue. Emergency sigmoidoscopy was performed, and continuous diffuse huge ulcerative lesions and ischemic changes were observed from the mid rectum to the mid sigmoid colon (Fig. I).

The severe abdominal pain persisted on physical examination, the contrast of the terminal ileum on ACTA diminished, and an ischemic change was confirmed on sigmoidoscopy to determine the emergency operation. The intraoperative findings showed small bowel necrosis from the terminal ileum to approximately $40 \mathrm{~cm}$ of the proximal ileum, necrotic changes of the mesentery, and focal serosal necrosis over the whole colon, including the sigmoid colon (Fig. 2). Finally, a temporary ileostomy was performed after subtotal colectomy. Pathological findings showed a diffuse mural infarct with serosal 
abscess formation in the colon and a transmural infarct in the terminal ileum (Fig. 3).

He had decreased serum creatinine level on postoperative day I, the abdominal pain disappeared on postoperative day 2 , and his serum creatinine level returned to its normal level in urine output and the renal replacement was discontinued on postoperative day 3 . On the $10^{\text {th }}$ day after surgery, he was discharged without any abnormal findings.

\section{DISCUSSION}

Ischemic colitis can be diagnosed accurately by combining history-taking; physical, laboratory, radiological, and endoscopic examinations; and biopsy. Our patient's medical history indicated no thrombotic events, and blood tests or other specific evaluations revealed no coagulopathy of any type. Therefore, we estimated the cause of the vascular obstruction and venous infarction to be decompression sickness after scuba diving. Owing to the absence of an underlying disease treated with hyperbaric oxygen therapy, we performed conservative management through intravascular fluid resuscitation, use of broad-spectrum antibiotics, and continuous renal replacement therapy and close monitoring. However, diagnostic laparotomy was performed because of severe abdominal pain, follow-up abdominal CT and ischemic change on colonoscopy.

As a diver descends into the water and breathes under elevated pressure, the amounts of oxygen and nitrogen in the tissues increase according to Henry's law. When the diver returns to the surface, the sum of the gas tension in the tissue exceeds the ambient pressure and releases the free gas in bubble form. ${ }^{[8]}$ The bubbles may have diverse and complex effects on the body from direct obstruction of blood flow, disturbance of lymphatic flow, direct stimulation, or nerve damage by inflammatory mediators. These effects can be mild, cause sensory abnormalities, and in severe cases, lead to paralysis and death. ${ }^{[9]}$

The primary treatment for decompression sickness is recompression in a hyperbaric chamber and breathing with $100 \%$ oxygen. ${ }^{[10]}$ This process brings on a large diffusion gradient that reduces the rate of new bubble formation and reduces the size of existing bubbles. ${ }^{[1]}$ Appropriate treatment of decompression sickness is usually effective; especially when starting early after injury, the residual effect is unremarkable. Most residual effects resolve over time, but some residual effects may be permanent. ${ }^{[12]}$

Air embolism may cause ischemic colitis by reducing blood flow through the mesenteric vasculature. Ischemic colitis can be divided into two groups, full-thickness with gangrene and partial thickness (mucosa and submucosa). Full-thickness is temporary in most cases and can be managed with conservative therapy without causing full-thickness necrosis. ${ }^{[13]}$ It is rarely diagnosed as ischemic colitis after diving and extremely rarely progresses to full-thickness necrosis. ${ }^{[14]}$

\section{Conclusion}

Even after hyperbaric oxygen therapy for decompression sickness after scuba diving, ischemic colitis may occur by air embolism. If the symptoms are consistent with ischemic colitis after diving, comprehensive physical, laboratory, and radiologic examinations are required. Treatment depends on the severity of the symptoms and the patient's condition, but it is important to consider surgical approaches.

Informed Consent: Written informed consent was obtained from the patient for the publication of the case report and the accompanying images.

Ethics Approval and Consent to Participate: This case report was approved by the Institutional Review Board (IRB). IRB No. CNUH-EXP-20I8-287.

Peer-review: Internally peer-reviewed.

Authorship Contributions: Concept: E.S.C., J.K.J.; Design: E.S.C.; Supervision: E.S.C.; Fundings: J.K.J.; Materials: E.S.C.; Data: E.S.C., J.K.J., H.D.K.; Analysis: E.S.C., H.D.K.;; Literature search: E.S.C.; Writing: E.S.C.; Critical revision: J.K.J., H.D.K.

Conflict of Interest: None declared.

Financial Disclosure: The autors declared that this study has received no financial support.

\section{REFERENCES}

1. Hagberg M, Ornhagen H. Incidence and risk factors for symptoms of decompression sickness among male and female dive masters and instructors-a retrospective cohort study. Undersea Hyperb Med 2003;30:93-102.

2. Newton HB. Neurologic complications of scuba diving. Am Fam Physician 2001;63:2211-18.

3. Sun Q, Gao G. Decompression Sickness. N Engl J Med 2017;377:1568.

4. Lundgren CE, Ornhagen H. Nausea and abdominal discomfort--possible relation to aerophagia during diving: an epidemiologic study. Undersea Biomed Res 1975;2:155-60.

5. Hunter JD, Roobottom CA, Bryson PJ, Brown C. Conservative management of gastric rupture following scuba diving. J Accid Emerg Med 1998;15:116-7. [CrossRef]

6. Gertler SL, Stein J, Simon T, Miyai K. Mesenteric venous thrombosis as sole complication of decompression sickness. Dig Dis Sci 1984;29:91-5.

7. Tetzlaff K, Shank ES, Muth CM. Evaluation and management of decompression illness--an intensivist's perspective. Intensive Care Med 2003;29:2128-36. [CrossRef]

8. Barratt DM, Harch PG, Van Meter K. Decompression illness in divers: a review of the literature. Neurologist 2002;8:186-202. [CrossRef]

9. Vann RD, Butler FK, Mitchell SJ, Moon RE. Decompression illness. Lancet 2011;377:153-64. [CrossRef]

10. Cianci P, Slade JB Jr. Delayed treatment of decompression sickness with short, no-air-break tables: review of 140 cases. Aviat Space Environ Med 2006;77:1003-8.

11. Hyldegaard O, Møller M, Madsen J. Effect of He-O2, O2, and N2O-O2 breathing on injected bubbles in spinal white matter. Undersea Biomed Res 1991;18:361-71.

12. Thalmann ED. Principles of US NAVY recompression treatments for decompression sickness. In: Bennett PB, Moon RE, eds. Proceedings 
of the Decompression Workshop 1996. Kenshington: Undersea and

Hyperbaric Medical Society; 1996.p.75-95.

13. Washington C, Carmichael JC. Management of ischemic colitis. Clin
Colon Rectal Surg 2012;25:228-35. [CrossRef]

14. Payor AD, Tucci V. Acute ischemic colitis secondary to air embolism after diving. Int J Crit Illn Inj Sci 2011;1:73-8.

\section{OLGU SUNUMU - ÖZET}

\section{Tüplü dalış sonrası gelişen akut iskemik kolit için cerrahi yaklaşım: Olgu sunumu}

\section{Dr. Eun Soo Choi, ${ }^{1}$ Dr. Han Deok Kwak, ${ }^{2}$ Dr. Jae Kyun Ju²}

${ }^{1}$ KS Hastanesi, Genel Cerrahi Kliniği, Gwangju-Kore

${ }^{2}$ Chonnam Ulusal Üniversite Hastanesi, Genel Cerrahi Bölümü, Kolorektal Cerrahi Bölümü, Gwangju, Kore

Tüplü dalış sırasında dekompresyon nedeniyle ortaya çıkabilecek klinik belirtiler büyük ölçüde değişmekle birlikte esas olarak gastrointestinal sistemde sadece hafif semptomlar bildirilmiştir. Özellikle, hava embolisinin neden olduğu iskemik kolit nadirdir. Biz başarısız konservatif tedavi uygulanan ancak cerrahi olarak başarılı bir şekilde tedavi edilen tam kalınlıkta iskemik kolit olgusunu sunuyoruz. Bildirdiğimiz hususlar tüplü dalıştan sonra dekompresyonun gastrointestinal sistemde ciddi semptomlara neden olabileceğini ve cerrahi bir yaklaşım gerektirebileceğini düşündürmektedir. Tedavi semptomların şiddetine ve hastanın durumuna bağı olmakla birlikte cerrahi yaklaşımlar düşünülmelidir. Anahtar sözcükler: Akut iskemik kolit; cerrahi yaklaşım; dekompresyon hastalığı; hava embolisi; tüplü dalış.

Ulus Travma Acil Cerrahi Derg 2020;26(3):482-485 doi: 10.14744/tjtes.2019.67523 